\title{
Pengaruh Pengetahuan Wajib Pajak, Kesadaran Wajib Pajak Terhadap Motivasi Membayar Pajak Dengan Penerapan UU Tax Amnesty Sebagai Variabel Moderating Pada KANWIL DJP SUMUT I MEDAN
}

\author{
Ikhsan Abdullah \\ Edisah Putra Nainggolan \\ Program Studi Akuntansi Fakultas Ekonomi Bisnis \\ Universitas Muhammadiyah Sumatera Utara \\ Jln. Mukhtar Basri No. 3 Medan Indonesia \\ Coresponden; aikhsan7821@yahoo.com \\ Coresponden; ediputrafeumsu@gmail.com
}

\begin{abstract}
Abstrak
Penelitian ini bertujuan untuk memberikan bukti empiris tentang pengaruh Pengetahuan Wajib Pajak, Kesadaran Wajib Pajak Terhadap Motivasi Membayar Pajak Dengan Penerapan UU Tax Amnesty Sebagai Variabel Moderating Pada Kanwil DJP Sumut I Medan. Diharapkan dengan penelitian ini akan memberikan masukan dan gambaran tentang motivasi wajib pajak dalam melaksanakan kewajiban perpajakannya. Penelitian ini sekaligus menjadi bahan masukan dan evaluasi bagi pemerintah dalam pelaksanaan undang-undang pengampunan pajak (tax amnesty). Penelitian ini menggunakan angket dengan metode simple random sampling. Data diolah dengan menggunakan analisis regresi linier berganda, untuk memperoleh perngaruh dalam setiap variable penelitian. Penelitian ini juga menggunakan moderating regression analisys (MRA) dalam menguji apakah penerapan undang undang pengampunan pajak (tax amnesty) dapat memoderasi hubungan antara pengetahuan wajib pajak dan kesadaran wajib pajak terhadap motivasi membayar pajak. Berdasarkan hasil dari penelitian dan pembahasan didapati bahwa ada pengaruh Pengetahuan Wajib Pajak dan kesadaran Wajib Pajak secara persial dan simultan terhadap motivasi membayar pajak
\end{abstract}

Kata kunci : Pengetahuan, kesadaran, motivasi dan tax amnesty

\begin{abstract}
This study aims to provide empirical evidence about the effect of taxpayer knowledge, taxpayer awareness on the motivation to pay taxes with the application of the tax amnesty law as a moderating variable in the North Sumatra I Regional Tax Office. It is expected that this research will provide input and an overview of the motivation of taxpayers in carrying out their tax obligations. This research also serves as input and evaluation material for the government in implementing the tax amnesty law. This study uses a questionnaire with simple random sampling method. Data is processed using multiple linear regression analysis, to obtain influence in each research variable. This study also uses moderating regression analysis (MRA) in testing whether the application of the tax amnesty law can moderate the relationship between taxpayer knowledge and taxpayer awareness of the motivation to pay taxes. Based on the results of the study and discussion it was found that there was an effect of Tax Skill Knowledge and Taxpayer awareness on a persistent and simultaneous motivation to pay taxes.
\end{abstract}

Keywords: knowledge, awareness, motivation and tax amnesty 
Liabilities Jurnal Pendidikan Akuntansi

e-ISSN 2620-5866

Volume 1. No.2 Agustus 2018 (181-191)

https://doi.org/10.30596/liabilities.v1i2.2230

\section{PENDAHULUAN}

Pembangunan infra struktur yang semakin meningkat pesat memaksa pemerintah untuk bekerja keras dalam hal mendorong peningkatan penerimaan Negara. Salah satu penerimaan Negara yang menjadi penopang pembangunan adalah pajak. Menurut data APBN 2016 target penerimaan pajak adalah sebesar 1.546 triliun dan penerimaan Negara bukan pajak sebesar 273,8 triliun (kemenkeu.go.id). Tentu dapat dilihat bahwa pajak masih merupakan andalan pemerintah dalam hal penerimaan Negara sebagai modal pembangunan nasional dalam rangka untuk mewujudkan kesejahteraan bagi masyarakat. Besarnya peranan penerimaan pajak dalam pembiayaan pembangunan nasional, direktorat jenderal pajak sebagai instansi pemerintah yang mengelola dan bertanggung jawab terhadap penerimaan pajak melakukan berbagai upaya melalui program intensifikasi dan ekstensifikasi dalam bidang perpajakan. Tentunya keberhasilan dalam hal program ini tidak hanya bergantung pada pemerintah dalam hal ini direktorat jenderal pajak tapi juga sangat bergantung pada pengetahuan dan kesadaran wajiib pajak dalam memenuhi kewajiban perpajakannya.

Nurmantu

menyatakan bahwa semakin tinggi tingkat pendidikan atau pengetahuan wajib pajak, maka semakin mudah pula bagi mereka untuk memahami peraturan perpajakan dan semakin mudah pula wajib pajak memenuhi kewajiban perpajakannya. Pemerintah telah melakukan upaya untuk menambah pengetahuan bagi para Wajib Pajak, salah satunya adalah melalui penyuluhan pajak. Penyuluhan perpajakan atau sosialisasi perpajakan merupakan suatu upaya Ditjen Pajak khususnya KPP untuk memberikan pengertian informasi, dan pembinaan kepada masyarakat mengenai segala sesuatu yang berhubungan dengan peraturan perundang-undangan perpajakan. Adanya sosialisasi perpajakan diharapkan akan tercipta partisipasi yang efektif di masyarakat dalam memenuhi hak dan kewajiban sebagai Wajib Pajak dalam memenuhi perpajakannya.

Faktor lainnya yang sangat penting dalam hal penerimaan pajak adalah kesadaran wajib pajak. Sejak dilaksanakannya reformasi perpajakan pada tahun 1985 pemenuhan kewajiban perpajakan di Indonesia dilaksanakan dengan system self assessment. System ini memberikan kebebasan pada wajib pajak untuk menghitung, membayar dan melaporkan kewajiban perpajakannya kepada Negara dengan kesadaran sendiri. Tentunya pemerintah berkeinginan untuk meningkatkan jumlah wajib pajak dengan tujuan akhir untuk meningkatkan jumlah penerimaan Negara dari pajak. 
Liabilities Jurnal Pendidikan Akuntansi

e-ISSN 2620-5866

Volume 1. No.2 Agustus 2018 (181-191)

https://doi.org/10.30596/liabilities.v1i2.2230

Dalam upaya meningkatkan kesadaran dan membantu wajib pajak dalam hal memenuhi kewajiban perpajakannya, pemerintah meluncurkan sebuah terobosan baru yang disebut dengan pengampunan pajak (tax amnesty) melalui undang undang no.11 tahun 2016 tentang pengampunan pajak. Amnesti pajak adalah program pengampunan yang diberikan oleh Pemerintah kepada Wajib Pajak meliputi penghapusan pajak yang seharusnya terutang, penghapusan sanksi administrasi perpajakan, serta penghapusan sanksi pidana di bidang perpajakan atas harta yang diperoleh pada tahun 2015 dan sebelumnya yang belum dilaporkan dalam SPT, dengan cara melunasi seluruh tunggakan pajak yang dimiliki dan membayar uang tebusan. (UU No.11/2016)

Awal diluncurkan program ini mendapat pro dan kontra di tengah-tengah masyarakat. Ada yang setuju namun banyak juga pihak yang meragukan program pemerintah ini akan berjalan. Bahkan ada juga beberapa pihak yang menggugat pelaksanaan program pemerintah ini dengan menggugat pelaksanaan undang-undang tax amnesty ke Mahkamah Konstitusi. Sampai sekarang proses tersebut masih berjalan dan masih kita tunggu kemana akan bermuara.

Namun terlepas dari pro dan kontra terhadap program pengampunan pajak, nampaknya program ini telah berhasil menambah penerimaan negera dari sektor pajak. Sampai dengan berakhirnya periode pertama pelaksanaan tax amnesty pada tanggal 30 september 2016, Jumlah penerimaan uang tebusan amnesti pajak (tax amnesty) hingga Jumat (30/9/2016), pukul 11.42 WIB, mencapai Rp94,6 triliun, atau sekitar $57 \%$ dari target penerimaan uang tebusan sebesar Rp165 triliun hingga akhir program Maret 2017. Total jumlah harta yang terkumpul dalam program amnesti pajak di hari terakhir periode pertama mencapai Rp3.280 triliun yang terdiri dari deklarasi harta dalam negeri Rp2.247 triliun, deklarasi harta luar negeri Rp900 triliun. Berdasarkan laman resmi Direktorat Jenderal Pajak Kementerian Keuangan di www.pajak.go.id/statistik-amnesti yang diakses di Jakarta, Jumat (30/9/2016) pukul 11.42 WIB, total Surat Pernyataan Harta (SPH) yang disampaikan mencapai 315.911 SPH dengan total harta Rp3.279 triliun.(www.pajak.go.id)

Keberhasilan dalam penerimaan pajak pada periode pertama pelaksanaan tax amnesty tentu akan berdampak positif bagi perekonomian nasional dan baik buat pembangunan. Keberhasilan ini tentu tidak terlepas dari motivasi wajib pajak dalam membayar pajak. Dalam rangka meningkatkan motivasi wajib pajak khususnya pada periode kedua penerapan program tax amnesty pihak dirjen pajak harus gencar melakukan sosialisasi

ketengah-tengah 
Liabilities Jurnal Pendidikan Akuntansi

e-ISSN 2620-5866

Volume 1. No.2 Agustus 2018 (181-191)

https://doi.org/10.30596/liabilities.v1i2.2230

masyarakat mengenai manfaat pajak dan manfaat langsung yang diterima wajib pajak dalam program tax amnesty. Dengan adanya sosialisasi tersebut diharapkan dengan sendirinya motivasi masyarakat akan semakin kuat dan dalam memenuhi kewajiban perpajakannya.

Masyarakat juga akan merasa aman dengan mengikuti amnesty pajak, sesuai dengan slogan yang di dengungkan oleh direktoran jenderal pajak yaitu ungkap, tebus dan lega. Dimana wajib pajak bersedia melaporkan seluruh harta yang dimilikinya dan akan membayar tebusan untuk mendapatkan pengampunan pajak dan pelepasan hak Negara untuk menagih pajak yang seharusnya terutang dari pengungkapan harta yang dilakukan oleh wajib pajak kepada Dirjen pajak. Setelah itu wajib pajak akan merasa lega karena akan menerima pengampunan pajak dimana pajak yang terutang akan dihapuskan dan juga terbebas dari sanksi pidana dibidang

perpajakan.(www.pajak.go.id).

Gaung pelaksanaan program pengampunan pajak juga mendapat sambutan yang sangat positif di sumatera utara. Menurut data dari kanwil DJP Sumut I jumlah penerimaan pajak sampai pada akhir periode I program tax amnesty meliputi wajib pajak orang pribadi mencapai angka 17.733 orang dengan nilai tebusan sebesar 3,1 triliun dan untuk wajib pajak badan berjumlah
2.695 Wajib pajak badan dengan jumlah tebusan 334,31 milyar. Keberhasilan penererapan tax amnesty di DJP Sumut I merupakan terbesar setelah pulau jawa dan merupakan peringkat ke Sembilan se Indonesia. Keberhasilan ini akibat dukungan yang sangat kuat dari masyarakat sumatera utara dalam program pengampunan pajak. Dukungan tersebut dibuktikan dengan kesadaran wajib pajak dalam melaksanakan pembayaran kewajiban perpajakannya. Keberhasilan tersebut juga tidak terlepas dari sosialisasi gencar yang dilakukan oleh kanwil DJP Sumut I dalam rangka meningkatkan pengetahuan masyarakat akan kewajiban perpajakannya yang akhirnya menumbuhkan motivasi masyarakat dalam membayar pajak.

Pentingnya penelitian tentang motivasi masyarakat dalam membayar pajak sangat penting dilakukan, untuk meberikan masukan dan gambaran secara empirs tentang fenomena dan gejalan di tengahtengah masyarakat dalam hal melakukan pembayaran kewajiban perpajakan. Seperti kita ketahui bersama bahwa motivasi masyarakat dewasa ini masih sangat rendah dalam hal membayar kewajiban perpajakan, bahkan beberapa kasus tentang perpajakan sangat sering kita jumpai di tengah-tengah masyarakat. Kasus yang terakhir kita lihat adalah tewasnya dua orang juru sita pajak di KPP pajak Sibolga. Hal ini 
Liabilities Jurnal Pendidikan Akuntansi

e-ISSN 2620-5866

Volume 1. No.2 Agustus 2018 (181-191)

https://doi.org/10.30596/liabilities.v1i2.2230

menunjukkan bahwa masyarakat dua yaitu sumber data primer dan masih sangat apatis dalam hal kewajiban perpajakannya yang mengakibatkan masyarakat menjadi kalap ketika mengetahui banyaknya kewajiban perpajakan yang harus di penuhi. Tentunya hal tersebut tidak terlepas dari pengetahuan masyarakat tenang pajak dan kesadarannya membayar

\section{METODE PENELITIAN}

Penelitian ini merupakan penelitian lapangan (field research) dengan menggunakan pendekatan asosiatif yaitu penelitian yang bertujuan untuk mengetahui hubungan antara dua variabel atau lebih. Dengan penelitian ini maka akan dapat dibangun suatu teori yang dapat berfungsi untuk menjelaskan, meramalkan, dan mengontrol suatu gejala.(Sugiono, 2008). Sumber data dalam penelitian dibedakan menjadi

\begin{tabular}{|ll|l|l|l|l|l|}
\hline \multicolumn{2}{|c|}{} & \multicolumn{2}{l|l}{$\begin{array}{l}\text { Unstandardized } \\
\text { Coefficients }\end{array}$} & $\begin{array}{l}\text { Standardized } \\
\text { Coefficients }\end{array}$ & & Sig. \\
\cline { 2 - 6 } Model & B & Std. Error & Beta & t & Sig. \\
\hline 1 & (Constant) & 21,583 & 1,704 & & 12,668 &, 000 \\
X1 &, 199 &, 055 &, 260 & 3,638 &, 000 \\
X2 &, 235 &, 052 &, 323 & 4,501 &, 000 \\
Z &, 140 &, 056 &, 186 & 2,491 &, 014 \\
\hline
\end{tabular}

Berdasarkan tabel coefficient

(5.4) diatas dapat dibuat persamaan regresi berganda sebagai berikut :

$$
\mathbf{Y}=\boldsymbol{\beta}_{0}+\boldsymbol{\beta}_{1} \mathbf{X}_{1}+\boldsymbol{\beta}_{2} \mathbf{X}_{2}+\boldsymbol{\beta}_{3} \mathbf{X}_{3}+\mathbf{e}
$$

Motivasi bayar Pajak $=21,583+$ 0,199 PWp + 0,235 Keswajib pajak + 0,140 P UU + e

Nilai konstanta sebesar 21,583 artinya jika nilai Pengetahuan Wajib sumber data sekunder.Teknik Pengumpulan Data menggunakkan daftar Pertanyaan (Questionnaire), yaitu dengan memberikan daftar pertanyaan kepada para wajib pajak baik pribadi dan badan yang menjadi responden dalam penelitian ini. Studi Dokumentasi, yaitu dengan pengumpulan dokumen-dokumen yang berkaitan dengan masalah yang diteliti. Populasi dalam penelitian ini adalah semua wajib pajak yang terdaftar pada kantor wilayah Sumatera Utara I Medan baik wajib pajak orang pribadi dan wajib pajak badan. Tehnik analisis data yang digunakan dalam penelitian ini adalah regresi linier berganda

\section{HASIL DAN PEMBAHASAN}

Pajak, Kesadaranwajib pajak dan Penerapan UU 0 (nol) maka Motivasi Membayar Pajak bernilai 21,583.

Koefisien regresi variabel X1 (Pengetahuan Wajib Pajak) sebesar 0.199, artinya jika variabel independen lainnya nilainya tetap dan variabel X1 (Pengetahuan Wajib Pajak) mengalami kenaikan sebesar $100 \%$ (1 kali) maka Motivasi 
Liabilities Jurnal Pendidikan Akuntansi

e-ISSN 2620-5866

Volume 1. No.2 Agustus 2018 (181-191)

https://doi.org/10.30596/liabilities.v1i2.2230

Membayar Pajak mengalami kenaikan sebesar 19,9\%. Koefisien bernilai positif artinya terjadi hubungan positif antara variabel Pengetahuan Wajib Pajak dengan Motivasi membayar Pajak, semakin naik variabel Pengetahuan Wajib Pjk maka semakin meningkat Motivasi Membayar Pajak.

Koefisien Regresi variabel X2 (Kesadaranwajib pajak) sebesar 0.235, artinya jika variabel independen lainnya nilainya tetap dan variabel X2 (Kesadaranwajib pajak) mengalami kenaikan sebesar 100\% (1 kali) maka Motivasi membayar Pajak mengalami kenaikan sebesar 23,5\%. Koefisien bernilai positif artinya terjadi hubungan positif antara variabel Objektivitas Kesadaraan Wajib Pajak dengan Motivasi Membayar Pajak, semakin naik variable Kesadaraan Wajib Pajak maka semakin Motivasi Membayar Pajak.

Koefisien Regresi variabel X3

(Penerapan UU) sebesar 0,140, artinya jika variabel independen lainnya nilainya tetap dan variabel X3 (Penerapan UU) mengalami kenaikan sebesar 100\% (1 kali) maka Kualitas Audit mengalami kenaikan sebesar $14,0 \%$. Koefisien bernilai positif artinya terjadi hubungan positif antara variabel Penerapan UU dengan Motivasi membayar Pajak, semakin naik variabel Penerapan UU maka semakin meningkat Motivasi Membayar Pajak.

\section{PENGUJIAN HIPOTESIS}

\author{
H1. Pengaruh Pengetahuan Wajib \\ Pajak terhadap Motivasi membayar \\ Pajak
}

Untuk melihat apakah ada pengaruh signifikan Pengetahuan Wajib Pajak terhadap Motivasi Membayar Pajak maka dapat dilakukan langkah sebagai berikut. Menentukan hipotesis berdasarkan nilai $\mathrm{t}_{\text {hitung: }}$ :

1. H0 : Tidak ada pengaruh Wajib Pajak terhadap Motivasi Membayar Pajak.

2. Ha : Ada pengaruh Wajib Pajak terhadap Motivasi Membayar Pajak.

Menetukan hipotesis dengan menggunakan nilai signifikasi dari variabel Motivasi Membayar Pajak. Adapun kriteria yang digunakan adalah :

1) Jika sig <0,05 maka H0 ditolak dan Ha diterima

2) Jika sig > 0,05 maka H0 diterima dan Ha ditolak.

Berdasarkan tabel 5.4 diatas dapat kita lihat nilai signifikansi dari variabel Pengetahuan Wajib Pajak adalah sebesar $0,00<$ dari 0.05 maka H0 ditolak dan Ha diterima.

H2: Pengaruh Kesadaran Wajib Pajak terhadap Motivasi Membayar Pajak

Untuk melihat apakah ada pengaruh signifikan Kesadaranwajib pajak 
Liabilities Jurnal Pendidikan Akuntansi

e-ISSN 2620-5866

Volume 1. No.2 Agustus 2018 (181-191)

https://doi.org/10.30596/liabilities.v1i2.2230

terhadap Motivasi Membayar Pajak maka dapat dilakukan langkah sebagai berikut. Menentukan hipotesis berdasarkan nilai $t_{\text {hitung: }}$

1) H0: Tidak ada pengaruh Kesadaranwajib pajak terhadap Motivasi Membayar Pajak.

2) $\mathrm{Ha}: \mathrm{Ada}$ pengaruh Kesadaranwajib pajak terhadap Motivasi Membayar Pajak.

Menetukan hipotesis dengan menggunakan nilai signifikasi dari variabel Kesadaran wajib pajak. Adapun kriteria yang digunakan adalah :

1) Jika sig $<0,05$ maka $\mathrm{H} 0$ ditolak dan Ha diterima

2) Jika sig > 0,05 maka H0 diterima dan Ha ditolak.

Berdasarkan tabel 5.4 diatas dapat kita lihat nilai signifikansi dari variabel kesadaran wajib pajak adalah sebesar $0,000>$ dari 0.05 maka H0 ditolak dan Ha diterima

\section{H3. Pengaruh Penerapan UU Tax Amnesty terhadap Motivasi Membayar Pajak}

Untuk melihat apakah ada pengaruh signifikan Penerapan UU Tax Amnesty terhadap Motivasi Membayar Pajak maka dapat dilakukan langkah sebagai berikut. Menentukan hipotesis berdasarkan nilai $\mathrm{t}_{\text {hitung: }}$

1) H0 : Tidak ada pengaruh Penerapan UU Tax Amnesty terhadap Motivasi Membayar Pajak.

2) $\mathrm{Ha}:$ Ada pengaruh Penerapan UU Tax Amnesty terhadap Motivasi Bayar Pajak

Menetukan hipotesis dengan menggunakan nilai signifikasi dari variabel UU Tax Amnesti. Adapun kriteria yang digunakan adalah :

1) Jika sig $<0,05$ maka $\mathrm{H} 0$ ditolak dan Ha diterima

2) Jika sig > 0,05 maka $\mathrm{H} 0$ diterima dan Ha ditolak.

Berdasarkan tabel 5.4 diatas dapat kita lihat nilai signifikansi dari variabel Penerapan UU Tax Amnesty terhadap Motivasi Byr Pajak adalah sebesar $0,14>$ dari 0.05 maka H0 diterima dan Ha ditolak.

\section{Uji F (Simultan)}

Untuk mengetahui tingkat signifikansi persamaan pengaruh variabel independen secara bersamaan terhadap variabel dependen digunakan uji $\mathrm{F}$ (F Test). Langkah-langkah pengujian: Menentukan formulasi Ho dan $\mathrm{Ha}$ Ho $=\beta=0$ : tidak ada pengaruh antara variabel independen (X) terhadap variabel dependen (Y).

$\mathrm{Ha}=\neq 0$ : ada pengaruh antara variabel independen $(\mathrm{X})$ terhadap variabel dependen (Y). Taraf nyata $\alpha=95 \%$

Derajat kebebasan F table $(\alpha, \mathrm{k}, \mathrm{n}-\mathrm{k}-$ 1), dimana:

$$
\begin{array}{r}
\alpha=0,05, \mathrm{k}=\text { jumlah variabel, } \mathrm{n} \\
=\text { jumlah sampel }
\end{array}
$$


Liabilities Jurnal Pendidikan Akuntansi

e-ISSN 2620-5866

Volume 1. No.2 Agustus 2018 (181-191)

https://doi.org/10.30596/liabilities.v1i2.2230

berdasarkan ketentuan Berdasarkan hasil tersebut diperoleh tersebut didapatkan angka derajat angka $\mathrm{F}$ tabel sebesar 2,65 (F tabel kebebasan $\quad \mathrm{F}$ tabel $=185-3-1=181 . \quad$ terlampir).

Tabel 5.5. ANOVA ${ }^{\mathrm{a}}$

\begin{tabular}{|c|c|c|c|c|c|c|}
\hline Model & & $\begin{array}{l}\text { Sum } \\
\text { Squares }\end{array}$ & df & Mean Square & $\mathrm{F}$ & Sig. \\
\hline 1 & $\begin{array}{l}\text { Regression } \\
\text { Residual } \\
\text { Total }\end{array}$ & $\begin{array}{l}2124,912 \\
3023,467 \\
5148,378\end{array}$ & $\begin{array}{l}3 \\
181 \\
184\end{array}$ & $\begin{array}{l}708,304 \\
16,704\end{array}$ & 42,403 &, $000^{\mathrm{b}}$ \\
\hline
\end{tabular}

a. Dependent Variable: $Y$

b. Predictors: (Constant), Z, X1, X2

Untuk memperbandingkannya maka ditentukan kriteria:

1) Jika $\mathrm{t}$ hitung $>\mathrm{t}$ tabel maka $\mathrm{H} 0$ ditolak dan Ha diterima

2) Jika $\mathrm{t}$ hitung $<\mathrm{t}$ tabel maka $\mathrm{H} 0$ diterima dan Ha ditolak

Berdasarkan hasil perhitungan SPSS pada tabel 4-6 didaptkan angka $\mathrm{F}$ tabel sebesar $42,403>2,65$, sehingga H0 ditolak dan $\mathrm{Ha}$ diterima. Artinya, ada pengaruh Pengetahuan wajib pajak, Kesedaraan wajib pajak, Penerapan
UU Tax Amnesty secara bersamaan terhadap Motivasi Membayar Pajak.

\section{H4 : Pengujian Hipotesis Dengan Variabel Moderasi}

Dalam pengujian ini adalah untuk melihat apakah Penerapan UU Tax Amnesty merupakan variabel moderating dalam penelitian ini, maka tahapan pengujian yang dilakukan dapat dilihat pada Tabel 5.7 berikut ini :

\begin{tabular}{|c|c|c|c|c|c|c|}
\hline \multirow{2}{*}{\multicolumn{2}{|c|}{ Model }} & \multicolumn{2}{|c|}{ Unstandardized Coefficients } & \multirow{2}{*}{$\begin{array}{l}\text { Standardized } \\
\text { Coefficients } \\
\text { Beta }\end{array}$} & \multirow[b]{2}{*}{$\mathrm{t}$} & \multirow[b]{2}{*}{ Sig. } \\
\hline & & B & Std. Error & & & \\
\hline \multirow[t]{6}{*}{1} & (Constant) & 39,189 & ,549 & & 71,409 &, 000 \\
\hline & Zscore: PWP & 1,209 & ,375 & ,229 & 3,227 &, 001 \\
\hline & Zscore: KWP & 1,356 & ,389 &, 256 & 3,483 & ,001 \\
\hline & Zscore: UUTA & 1,207 & ,397 & ,228 & 3,039 & ,003 \\
\hline & Moderator1 &, 187 &, 525 & ,020 &, 356 & ,722 \\
\hline & Moderator2 & 1,380 & ,459 &, 181 & 3,009 & ,003 \\
\hline
\end{tabular}

a. Dependent Variable: MMP

memoderasi hubungan antara variabel

Berdasarkan tabel diataas maka Pengetahuan wajib pajak dan ditentukan apakah UU Tax amnesti kesadaran wajib pajak terhadap 
Liabilities Jurnal Pendidikan Akuntansi

e-ISSN 2620-5866

Volume 1. No.2 Agustus 2018 (181-191)

https://doi.org/10.30596/liabilities.v1i2.2230

motivasi membayar pajak dengan ketentuan sebagai beriktu :

- Jika tingkat signifikansi moderator lebih besar dari 0,05 maka UU Tax Amnesti bukan merupakan variabel moderator

- Jika tingkat signifikansi moderator lebih besar 0,05 maka UU Tax Amnesti bukan merupakan variabel moderator

Berdasarka tabel coefisient diatas didapati bahwa nilai signifikani variabel moderator 1 adalah $0,722>$ 0,05 artinya UU tax amnesti tidak memoderasi hubunga antara pengetahuan wajib pajak terhadap motivasi membayar pajak. Selanjutnya moderator2 adalah sebesar 0,003 $<0,005$ artinya UU tax amnesti memoderasi hubungan antara Kesaradaran Wajib Pajak terhadap Motivasi membayar pajak.

\section{PEMBAHASAN}

Hasil penelitian ini menyatakan bahwa secara parsial Pengetahuan Wajib pajak berpengaruh secara signifikan terhadap Motivasi Membayar Pajak. Artinya semakin tinggi tingkat pengetahuanwajib pajak maka akan memotivasi wajib pajak dalam memenuhi kewajiban perpajakannya.

Hasil penelitian ini menunjukan bahwa secara parsial Kesadaran Wajib Pajak berpengaruh secara signifikan terhadap Motivasi Membayar Pajak. Artinya bahwa semakin tinggi tingkat kesadaran wajib pajak maka akan memotivasi wajib pajak dalam memenuhi kewajiban perpajakannya

Hasil penelitian ini menunjukkan bahwa secara simultan Pengetahuan Wajib Pajak, Kesadaran Wajib Pajak dan Penerapan UU Tax Amnesti berpengaruh terhadap Motivasi Membayar Pajak.

Hasil penelitian ini menunjukkan bahwa UU tax amnesti tidak memoderaasi hubungan antara pengetahuan wajib pajak terhadap motivasi membayar pajak. Artinya bahwa wajib pajak. Artinya bahwa wajib pajak tidak akan melakukan pembayaran kewajiban perpajakannya meskipun tau dengan adanya penerapan UU tax amnesti, karena memang sangat dibutuhkan kesadaran wajib pajak dalam melakukan pembayaran kewajiban perpajakannya.

Hasi penelitian ini menunjukkan bahwa UU tax amnesti memoderaasi hubungan antara kesadaran wajib pajak terhadap motivasi membayar pajak. Artinya bahwa dengan adanya penerapan UU tax amnesti akan semakin meningkatkan kesadaran wajib pajak dan memotivasi wajib pajak dalam melakukan pembayaran kewajiban perpajakannya.

\section{KESIMPULAN DAN SARAN}

\section{Kesimpulan}


Liabilities Jurnal Pendidikan Akuntansi

e-ISSN 2620-5866

Volume 1. No.2 Agustus 2018 (181-191)

https://doi.org/10.30596/liabilities.v1i2.2230

Berdasarkan hasil penelitian dan pembahasan maka dapat disimpulkan sebagai berikut :

1. Secara parsial, Pengetahuan Wajib Pajak berpengaruh signifikan terhadap Motivasi Membayar Pajak

2. Secara Parsial Kesadaran Wajib Pajak berpengaruh signifikan terhadap Motivasi Membayar Pajak

3. Secara Simultan Pengetahuan Wajib Pajak dan Kesadaran Wajib Pajak berpengruh signifikan terhadap Motivasi Membayar Pajak

4. Penerapan UU Tax amnesti tidak memoderasi hubungan antara Pengetahuan Wajib Pajak terhadap Motivasi Membayar Pajak

\section{Saran}

Adapun Saran sebagai berikut:

1. Penelitian ini dapat dikembangkan oleh praktisi dan akademisi sebagai bahan masukan untuk meningkatkan Motivasi Membayar Pajak

2. Berdasarkan hasil penelitian, perlu dilakukan penelitian ulang dengan menambah variabel-variabel lain yang mungkin mempengaruhi penilaian Motivasi Membayar Pajak.

\section{DAFTAR PUSTAKA}

Abdul Ghoni,. 2012. Pengaruh Motivasi dan Pengetahuan Wajib
Pajak terhadap Kepatuhan wajib pajak daerah. Jurnal Akuntansi Unesa

Depdiknas, 2008, "Kamus Besar Bahasa Indonesia", Gramedia Pustaka Indonesia

Fitria Ulfa "Pengaruh kesadaran Wajib Pajak dan pengetahuan perpajakan terhadap kepatuhan wajib pajak orang pribadi pada KPP Patama Medan Petisah, Medan

Herzberg, Fredrick. 2008. One More Time: How do You Motivate Employees? Boston : Harvard Bussiness Press

Irianto,2005. Politik Perpajakan: Membangun Demokrasi Negara. Yogyakarta: UII Press

Jatmiko. 2006. Pengaruh Sikap Wajib Pajak pada Pelaksanaan Sanksi Denda, Pelayanan Fiskus, dan Kesadaran Perpajakan Terhadap Kepatuhan Wajib Pajak Studi Empiris Terhadap Wajib Pajak Orang Pribadi di Kota Semarang. Unisversitas Diponegoro

Junarman (2014) Faktor-Faktor yang memotivasi masyarkat dalam membayar pajak bumi dan bangunan di kec. Pondok subang. Universitas Bengkulu

Megawati, 2014. Analisis FaktorFaktor Yang Mempengaruhi Motivasi Wajib Pajak Orang Pribadi Dalam Membayar Pajak Untuk Meningkatkan Penerimaan Pajak Pph Pasal 21 Pada Kpp Pratama Subang. Universitas Maranatha Bandung 
Liabilities Jurnal Pendidikan Akuntansi

e-ISSN 2620-5866

Volume 1. No.2 Agustus 2018 (181-191)

https://doi.org/10.30596/liabilities.v1i2.2230

Rolalita, 2016 Pengaruh Motivasi Membayar Pajak Dan Tingkat Pendidikan Terhadap Kepatuhan Wajib Pajak Orang Pribadi Pada Kantor Wilayah Direktorat Jenderal Pajak Daerah Istimewa Yogyakarta Tahun 2015, Universitas negeri Yogyakarta

Ratriana Dyah safri, Pengaruh kesadaran wajib pajak terhadap kepatuhan wajib pajak orang pribadi yang melakukan pekerjaan bebas ( studi diwilayah KPP Pratama Yokyakarta) tugas akhir, Yoyakarta 2013

Safri nurmantu, 2005, pengantar perpajakan. Jakarta ; Granit

Siti Kurnia Rahayu, 2010 .Perpajakan Indonesia : Konsep dan Aspek Formal, Yogyakarta : Graha Ilmu

Supriyati, 2009, Dampak Motivasi dan Pengetahuan Perpajakan Terhadap Kepatuhan Wajib Pajak. Sumihar Petrus Tambunan (2003), "Mengapa Kita Membayar Pajak," Berita Pajak, No. 1488/Tahun XXXV, p. 33 - 35

Supriyati dan Nur Hidayati, 2007, "Pengaruh Pengetahuan Pajak dan Persepsi Wajib Pajak Terhadap Kepatuhan Wajib Pajak" Jurnal Akuntansi dan Teknologi Informasi, Vol 7, No. 1 hal 41-50

Torgler, Benno, 2008. Introduction to the Special Issue on Tax Compliance and Tax Policy, Economic Analysis and Policy, The School of Economics and Finance, March, 38 (1),
Queensland University of Technology,Australia

UU.No.11/2016 Tentang Pengampunan Pajak (tax amnesty)

Veronica Carolina. (2009). Pengetahuan Pajak. Jakarta: SalembaEmpat

Widayati dan Nurlis. 2010. "Faktorfaktor yang Mempengaruhi Kemauan untuk Membayar Pajak Wajib Pajak Orang Pribadi yang Melakukan Pekerjaan Bebas", Jurnal SNA XIII

www. Kemenkeu.go.id

Purwoko, aditya “ Pengaruh pelaksanaan Selft Asessment System, Kualitas Pelayanan KPP dan Tingkat Pendidikan Terhadap Motivasi Wajib Pajak memenuhi kewajiban Pajak, Skripsi UIN , Jakarta 2008

Qomaria, Siti “ Analisis Pengaruh pengetahuan tentang pajak dan tingkat pendidikdn wajib pajak terhadap kesadaran membayar pajak, Skripsi UIN, Jakarta 2008

www.pajak.go.id 